\title{
Analysis of Besaman Music Rhythm Patterns
}

\author{
Hardiansyah Ay \\ Art Creation Study Program, Institut Seni Indonesia Yogyakarta \\ email: hardianja22@gmail.com
}

\begin{abstract}
Besaman (bersaman) is a daily mention of the Gayo people for art activities which are currently only known as saman dance. saman is a traditional Gayo art which includes music, dance and literature. Within the elements of music, dance and literature have an equally important portion, in which each type of art takes place in mutualism, such as the motion of creating music, music (melodic form of song and poetic structure) is considered in creating the rhythm of motion. In the perspective of dance music, saman is a dance that uses a form of music presentation internally, internally what is meant is music that arises or is produced by the dancer itself (without accompaniment of music). Music in besaman is produced by clapping hands, chest, thighs, finger flicks and vocals. Clapping hands, chest, thighs and flick fingers form a choreography in the dance. The forms of song melodies and literary structures adjust and are also adjusted in creating a form of musical rhythm as well as dance moves. Therefore, the Gayo community calls this form of art activity with the plait not just dancing saman, because the three types of music, dance and literature take an equally important role in doing this art.
\end{abstract}

Keywords: Besaman, Gayo, music, dance, choreography.

\begin{abstract}
ABSTRAK
Besaman (bersaman) merupakan penyebutan sehari-hari masyarakat Gayo untuk kegiatan seni yang saat ini hanya dikenal sebagai tari saman. saman merupakan sebuah kesenian tradisional Gayo yang di dalamnya terdapat unsur musik, tari dan sastra. Di dalam besaman unsur musik, tari dan sastra memiliki porsi yang sama pentingnya, yang mana masing-masing jenis kesenian tersebut terjadi secara mutualisme, seperti gerak menciptakan musik, musik (bentuk melodi nyanyian dan struktur syair) dipertimbangkan dalam menciptakan ritme gerak. Dalam perspektif musik tari, saman merupakan tarian yang menggunakan bentuk penyajian musik secara internal, Secara internal yang dimaksud adalah musik yang timbul atau dihasilkan oleh penari itu sendiri (tanpa pengiring musik). Musik dalam besaman dihasilkan dari tepukan tangan, dada, paha, jentikan jari dan vokal. Tepukan tangan, dada, paha dan jentikan jari membentuk koreografi dalam tarian. Bentuk melodi nyanyian dan struktur sastra menyesuaikan dan juga disesuaikan dalam menciptakan bentuk ritme musik sekaligus gerak tari. Oleh sebab itu masyarakat Gayo menyebut bentuk kegiatan seni ini dengan besaman bukan hanya menari saman, dikarena ketiga jenis seni musik, tari dan sastra mengambil peran yang sama pentingnya dalam melakukan kesenian ini.
\end{abstract}

Kata kunci: Besaman, Gayo, musik, tari, koreografi 


\section{INTRODUCTION}

Essentially besaman functions as a medium of communication between community groups, to convey messages, advice, mandate, praise and reproach that is wrapped in the form of art. There is a shift in function that is happening at the moment, saman is considered only as a form of dance and attraction, saman is no longer bound by its essence. In the midst of the Gayo besaman community is opium, this art becomes a medium of moral and religious education, a media of hospitality, a media to gather together, a media to laugh, a media looking for happiness.

Since UNESCO established saman as an intangible world cultural heritage in 2011, saman's art has risen to the surface, educational vehicles have been competing in learning and practicing saman which they consider to be dance, saman performances have almost never been left behind in every popular event until statehood. Many things are good from the effect of the determination and recognition of UNESCO on saman, at least this art is increasingly known and noticed. But for the Gayo people, they do not intend to just pass down the saman as an attraction and dance only. Gayo community intends to leave Saman with all its essence to the world.

Saman is a type of traditional body percussion music that still exists today. In practice, in addition to using the body as percussion, besaman also uses singing in the form of a single melody which is the body's percussion as an accompaniment. Each part in the besaman produces music, good for just a single song, to perform a solid, fast and complicated body percussion rhythm pattern. The section includes: Rengum, dering, jangin, saur, redet, gerpu, and nese.

- Rengum is an opening song in the song that is done by using hamming techniques in a low voice and without saer (lyrics). Its function is as a form of respect for the audience which also includes jangin.

- Dering is a song that continues after a sigh. In the ring usually use saer "Laila alla ahoo lahoyaa, sareee lalalem, a haa haa lahoyaa, e heee leem, etc.". Or "Huwoolesaa, huwolusee, lesalam alam alaikum, etc."

- Jangin is a term used for singing and this term is also interpreted as a song.

- Redet is a term used for repetition of jangin (song) but with a different saer. - Saur is a form of mention for vocal unison (singing together) 
- Gerpuk is a term for a dense, complicated rhythm with a fast tempo and this term is also interpreted as a climax

- Ne-sek is a word that is used for mentioning a bridge or a code / sign as a transition to cracking. Usually nese 'takes the form of an outside sentence.

Usually in a group each group has a minimum of three jangin (songs) to perform once and the parts described above are always repeated and adjusted to each selected jangin and the parts do not have to always repeat sequentially in every jangin. Usually the role of a ruler (leader in the company) is needed in determining the choice of structure and structure of the performance composition. Gayo as a whole like Gayo Lut who inhabit the area around Lake Lut Tawar, Gayo Deret or Gayo Linge who inhabit the area around Linge-Isaq and Gayo Lues who inhabit the area around Gayo Lues have similar idiom forms of singing, differing only in accent and articulation. In the saman these characteristics are identified by the term woof, tauk and gelduk. Woof which in Indonesian can be interpreted as twisted, tauk which means shouting and gelduk which is almost the same type as woof, only that it sounds audible has a firmer accent and looks like a discontinuous meeting. Criteria for choosing a ceh (singer) in besaman must be able to master each of these idioms well.

For the sake of presenting the best performances, in general, before performing, the saman players always do exercises, in order to choose the best and make choreography as well as music. In this process, saman already has a number of basic patterns that serve as a reference for developing music and movement. Usually the advanced players can spontaneously perform these patterns, so that only need to develop the form of movement and rhythm, then adjusted to the chosen fetus.

In an effort to document the basic forms of percussion rhythm of the saman's musical body, I transcribed them using western music notation, because the writing of western music notation is quite capable in summarizing and explaining sounds for percussion instruments. But to go to perfect and simpler new symbols are needed to be able to project the form of motion in the metal. For an explanation of the idiom of the song melodic idiom, I can only explain it in descriptive form. So far the form of song idioms in besaman still can only be learned orally. Efforts in documenting it 
using western music notation were considered to be in vain and there would be an error in the information regarding the form of the idiom of the song. This is because the western notation writing has not been able to summarize all sound events that occur in besaman, ranging from ornamentation symbols to the size of the sound frequency that has been set in western music notation. Thus it takes the form of symbols or new writing that can summarize and explain the sound events that occur in the art of saman.

\section{RESEARCH METHODS}

The instrumentation in the transcript of the basic patterns of the same percussion body rhythm music I use in the order of the letters $A, A$ ' , A' ', B, B', C, C ', $D, E, E^{\prime}$ and $F$. It aims in order to instruct the body parts used in the percussion music game at the same time. The explanation of the sequence of letters is as follows.

A: Patting the chest using the left hand

$A$ ': Patting the chest using the right hand

A ": Patting the chest using the right and left hand

$B$ : Patting the left thigh using the left hand

$B$ ': Patting the right thigh using the left hand

C: Patting the right thigh using the right hand

$C$ ': Patting the left thigh using the right hand

D: Pat your thighs using your right hand and left hand crossed

E: Clap your hands with your right hand above your left hand

E ': Clap your hands with your left hand above your right hand

F: Flick a finger.

Note: In besaman there are some rules of motion that must be obeyed. One of the provisions is made on the information letter $B$ and $C$, which is when patting the thigh with the hand on the same side, then pat using the back side of the palm. For example; when the right hand pats the right thigh then using the back side of the right palm, so does what happens if the left hand pats the left thigh. 


\section{DISCUSSION}

Transcripts of the basic archetypal forms of percussion music in saman are as follows.

\section{Basic Patterns of Saman I Music Rhythm}

\section{ritme saman pola Dasar I}

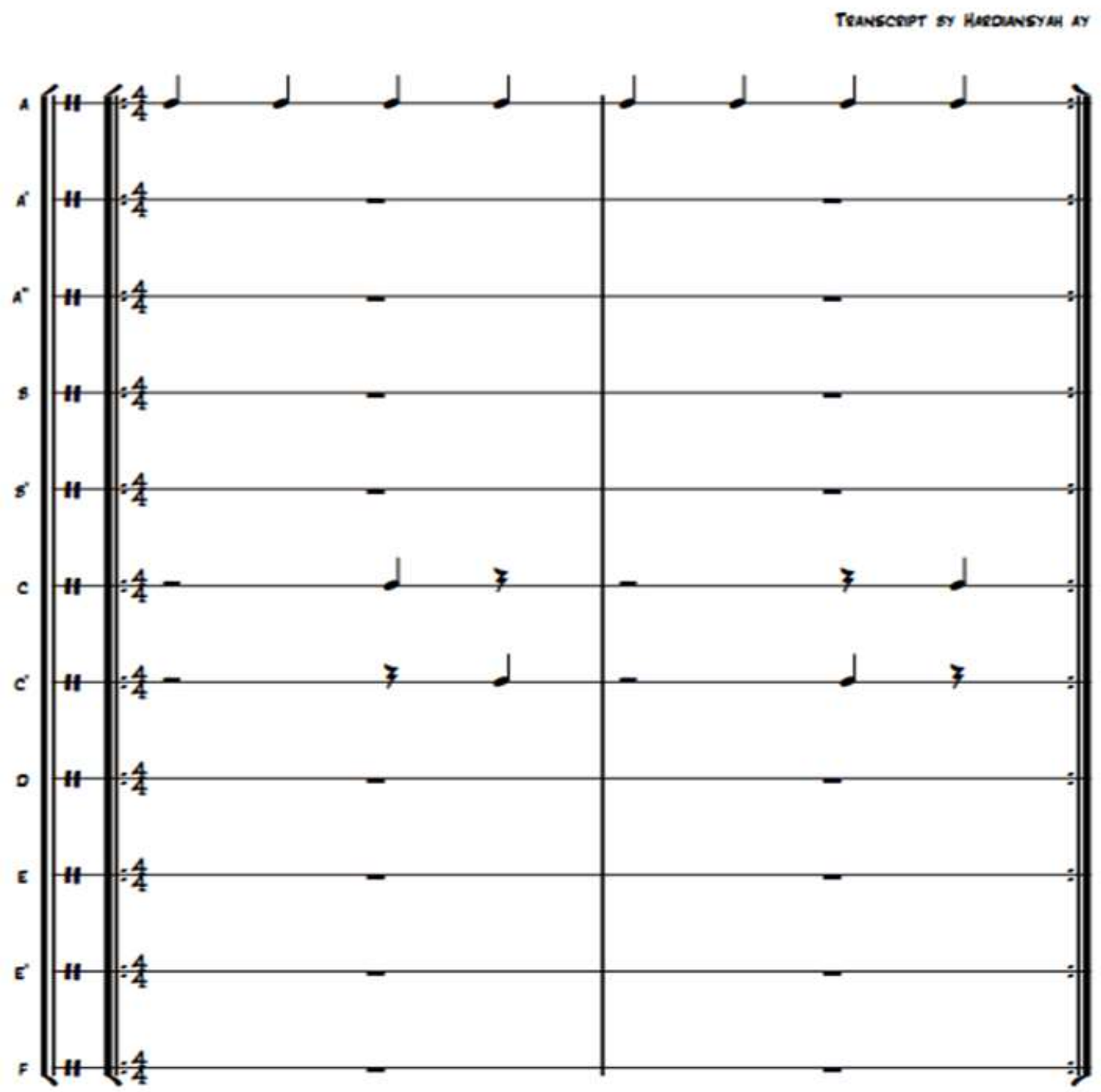

Figure 1.

Transcript of the basic rhythmic shape of the saman, left hand patting the chest and right hand patting the right and left thighs. 
The Basic Pattern of Saman Rhythm Music II

RITME SAMAN POLA DASAR ॥

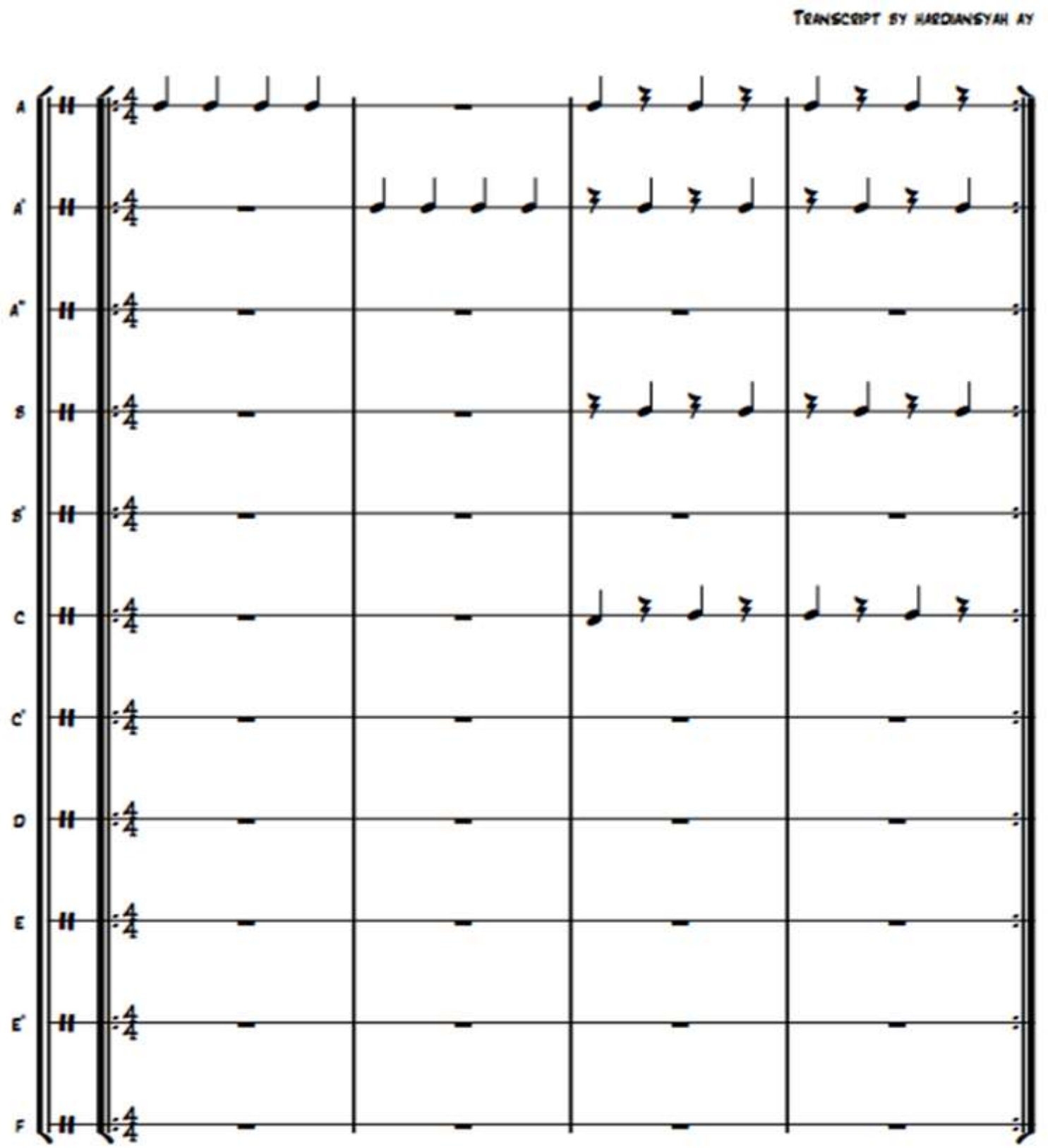

Figure 2.

Transcript form of the basic pattern of rhythm on the saman, left and right hands pat each other's chest and right and left thighs. 
The Basic Pattern of Saman Rhythm Music III

\section{Ritme Saman pola Dasar III}

TRANSCRIPT BY HARDIANSYAH AY

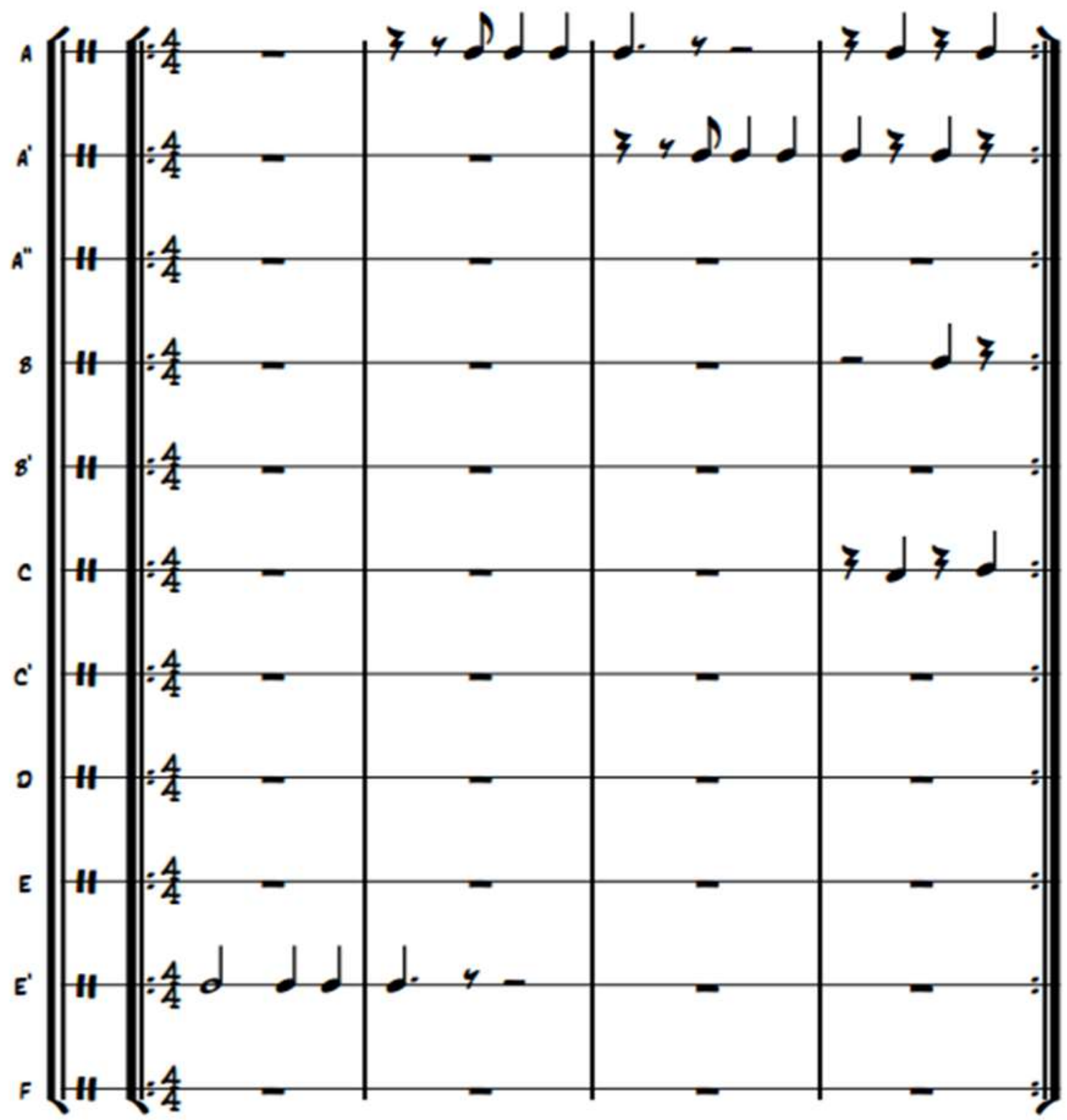

Figure 3.

The basic transcript of the rhythmic pattern of the saman, beginning with the clapping of the hands, then alternately clapping the chest with the left and right hands and clapping the left and right thighs with the right and left hands. 


\section{Examples of Gerpuk Pattern in Saman Music}

\section{Contoh pola ritme gerpuk saman}
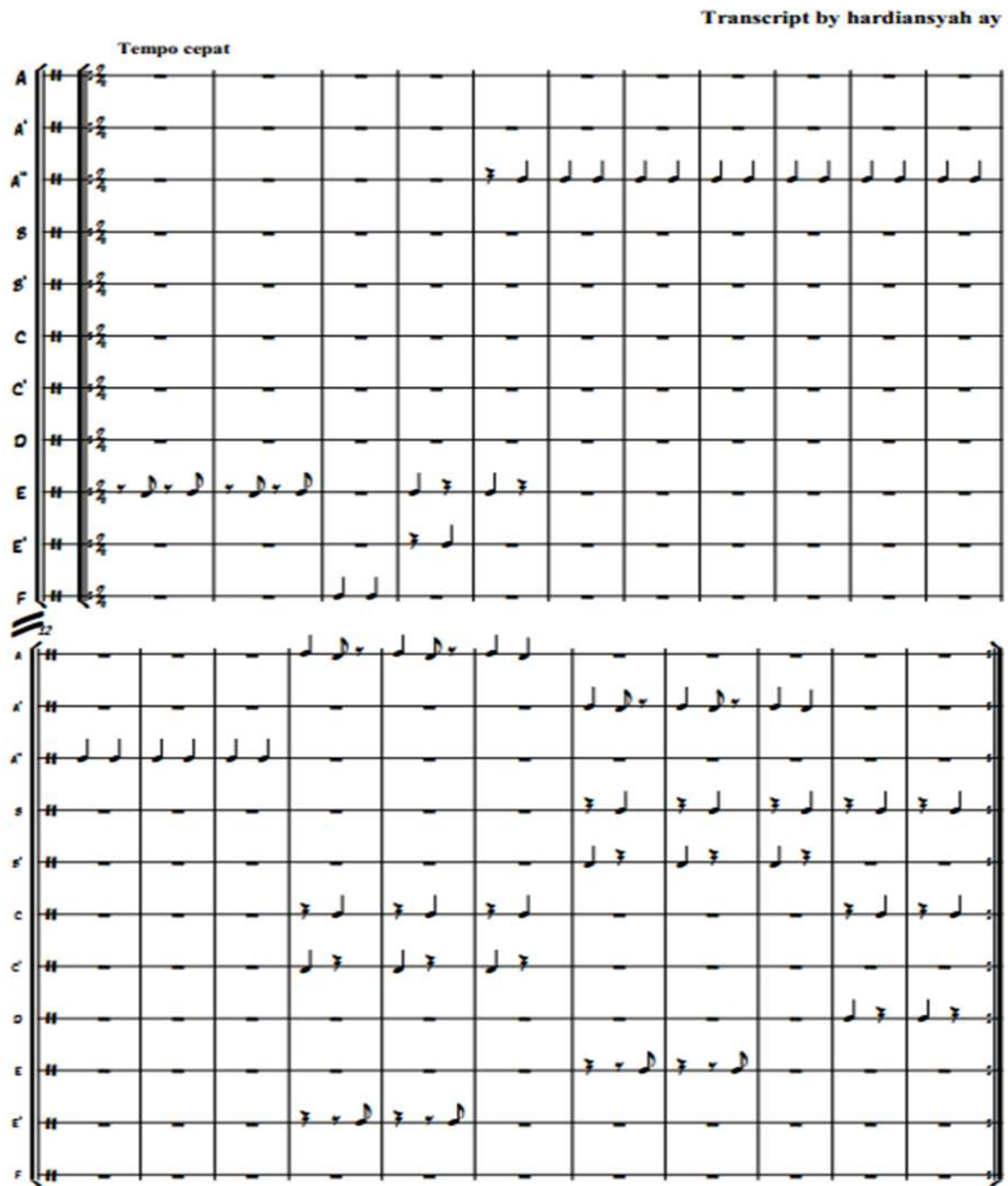

Figure 4.

Example of the pattern of groceries in saman music, beginning with applause then flicking fingers, then patting the chest with both hands and continuing by combining chest pats, thighs and clapping hands with a fast tempo. 


\section{CONCLUSION}

Saman is a traditional Gayo art that includes music, dance, and literature. In besaman elements of music, dance and literature have an equally important portion, in which each type of art occurs in mutualism. Music in besaman is produced by clapping hands, chest, thighs, finger flicks and vocals. Clapping hands, chest, thighs and flick fingers form a choreography in the dance. The forms of song melodies and literary structures adjust and are also adjusted in creating a form of musical rhythm as well as dance moves. That is why the Gayo people call this form of art activity with fun not just dancing saman.

Saman is a type of traditional body percussion music. In practice, in addition to using the body as percussion, besaman also uses singing in the form of a single melody which is the body's percussion as an accompaniment. Gayo as a whole like Gayo Lut who inhabit the area around Lake Lut Tawar, Gayo Deret or Gayo Linge who inhabit the area around Linge-Isaq and Gayo Lues who inhabit the area around Gayo Lues have similar idiom forms of singing, differing only in accent and articulation. In the saman these characteristics are identified by the term woof, tauk and gelduk.

For an explanation of the idiom of the melodic singing melodies, it can only be explained in descriptive form. So far, the way to learn the form of idioms in singing is still only oral. Efforts in documenting it using western musical notation are judged to be in vain, even there will be an error in information about the form of the idiom of the song. This is because the writing of western music notation has not been able to summarize all sound events that occur in the besaman, ranging from ornamentation symbols to the size of the sound frequency that has been set in western music notation, has not summarized and projected all sound events that exist in saman music. Thus it takes the form of symbols or new writing that can summarize, project and explain the sound events that occur in the art of saman. 


\section{REFERENCES}

Kartomi, Margaret. 2013. "The Saman Gayo Lues Sitting Song-Dance and its Recognition as an Item of Intangible Cultural Heritage". Yearbook for Traditional Music, Vol. 45 (pp.97-124). International Council for Traditional Music.

Melalatoa, M.J. 1997. Kebudajaan Gajo. Djakarta: Koordinator Asistensi Kabupaten Atjeh Tengah. 